\title{
Hidden from Scholarly Eyes for a Century: An unknown Bāysunghurī manuscript sheds new light on his court and library ${ }^{1}$
}

\section{SHIVA MIHAN}

\begin{abstract}
This paper introduces a dual-text manuscript produced in 833/1430 at Herat in the library of the Timurid prince, Bāysunghur (1399-1437), which has escaped previous scholarly attention. Its scribe, Sa'd al-Mashhadī, was previously known only for his copy of the Tärīkh-i Jahāngushā of 'Atā-Malik Juvaynī, as well as reports on his works in the Arża-dāsht by Bāysunghur's chief librarian, Ja far Tabrīzì, where he is referred to as Maulānā Sa'd al-Dīn. However, there is no other information about Sa'd as a calligrapher or an artist in contemporary or later sources. After a brief description of the manuscript, which bears the name of Baysunghur on its binding, the article attempts to discover a fuller picture of Sa'd al-Mashhadī's identity. A number of biographical dictionaries appear to equate him with a poet called Häfiz Sa'd, an exact contemporary who was also a prominent riddle writer, evidently attached to the court of Bāysunghur. This investigation in turn provides further evidence of an intellectual exchange between the courts of Bāysunghur Mīrzā and Ibrāhìm-Sultan, where the celebrated writer 'Alī Yazdī also composed riddles, including some concerning Sa'd al-Din.
\end{abstract}

Key words: Bāysunghur, Sa 'd al-Mashhad̄̄, Hāfiz Sa'd, Arża-dāsht, riddles

\section{Introduction}

The output of manuscripts produced in the celebrated library of the Timurid prince, Bāysunghur Mīrzā, (1399-1437), has attracted ample scholarly attention for more than a century. ${ }^{2}$ However, there are still several examples of the Herat School's arts of the book

\footnotetext{
${ }^{1}$ I am grateful to Prof. Charles Melville, for his valuable help and support in completing this article.

${ }^{2}$ Among the earliest studies in the $20^{\text {th }}$ century is Martin (1912), in which he refers to the kitäbkhāna as 'Bāysunghur's Academy'. Some other scholarly works, mainly centred on Bāysunghur's library, include the comprehensive research done by Thomas Lentz for his unpublished $\mathrm{PhD}$ dissertation: "Painting at Herat under Baysunghur ibn Shah Rukh" (1985); Roxburgh (2001): "Baysunghur's Library: Questions Related to its Chronology and Production"; Akimushkin (1997): "The Library-Workshop (kitābkhāna) of Bāysunghur-Mīrzā in Herat".
} 
under Bāysunghur's patronage that have not been properly identified or introduced. One such manuscript is preserved in a library in Istanbul.

This as yet neglected manuscript is preserved in the Yeni Cami library, catalogue no.

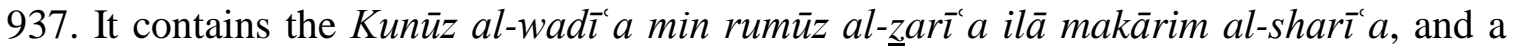
translation of al-Faraj ba'd al-shidda wa al-ż̀̄qa, copied by Sa'd al-Mashhadī in a carefully-written nasta ' $\bar{l} q$ script in 833/1430. It is an unillustrated codex in 475 ruled folios, set in 25 rows, decorated with two Bāysunghurī ex libris as well as three illuminated sarlauhs.

After describing the manuscript in detail, this paper will focus on confirming the identity of the scribe and his connection with the court of Bāysunghur.

\section{Codicology}

\section{The binding}

The 600-year history behind the Bāysunghurī productions that have survived to our time is sufficient to explain why they are seldom found in their original bindings; especially considering the fact that the output of Bāysunghur's royal workshop was moved and plundered several times after his death. ${ }^{3}$ Although not in pristine condition, the original cover of the Yeni Cami manuscript has been preserved in the course of conservations; this alone gives it considerable codicological significance.

The binding in medium and light brown leather has been restored at some point. The dark brown leather used in the course of its traditional conservation is easily distinguishable.

\footnotetext{
${ }^{3}$ Lentz (1985): pp. 134-135, believes that at least five original book-bindings executed for Bāysunghur are still extant: Kalīla va Dimna (833), Kalīla va Dimna (834), Tārīkh-i Issfahān (834), Tārīkh-i Ṭabarì (833), and Chahār Maqāla (835). In my opinion, the binding of the Tärīkh-i Ișfahān is from a later period.
} 
The original binding was evidently damaged along the edges and has been remounted carefully in its former place after the damaged parts were restored, both on the outer cover and inside. The spine is the sole part that had to be replaced. The cover is decorated with fine patterns that are tooled on the margins, enclosing a turanj (a pointed shamsa) and four corner pieces on the boards. A limited tooling adorns the doublures and the inside of the envelope flap. The spine of the flap, similarly tooled and with the same decorative motifs, exceptionally encompasses an inscription in sols (thulth) script, which reads:

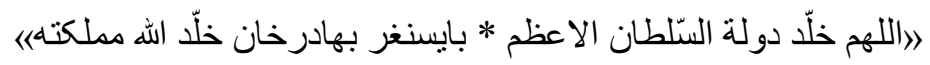

The age of the leather, as well as the inscription in the name of Bāysunghur, confirms the authenticity of the Bāysunghurī binding. Among other productions of his workshop, the only manuscript that now carries the name of Bāysunghur on its binding is the Kalīla va Dimna (833/1430), in the Topkapi Palace Library (H. 362). His name appears in Kufic on the arabesque-decorated cartouches on both the front and back doublures.

One other original binding that still protects its manuscript belongs to the Nașāyihn-i Iskandar, preserved in the Dublin Chester Beatty Library and catalogued as Ar. 4183. The copyist is Ja'far Bāysunghurī, and it is dated 829/1426. Its binding is the closest to Yeni Cami's in technique and design. Analogously, the original parts were saved and remounted on the repaired edges; however, in this case, the flap spine has been replaced in conservation and no inscription is witnessed, if it ever existed. It is made of medium brown leather of finest quality with very similar decorative motifs and the same subtle technique of tooling (fig. 1). The Nașāyih̆-i Iskandar's binding enjoys an absolutely pristine condition, whereas the Yeni Cami MS's is worn on the boards (fig. 2) This similarity eliminates doubts about the originality of Chester Beatty's MS, which was puzzling for its Ottoman-type green silk pasted on the sheets facing the doublures. ${ }^{4}$

\footnotetext{
${ }^{4}$ Roxburgh indicated the original binding for this MS in his list of Bāysunghurī productions in his lecture series ('Modeling Artistic Process: The Kitābkhāna and Arzadāsht', Yarshater Lecture Series, SOAS,
} 
Figure 1: The flap of the Yeni Cami MS (right) and the Nașāyih-i Iskandar (left)

\section{Figure 2: Binding, no. 937, Yeni Cami Library, Istanbul}

\section{The text}

The first part of the codex is a Persian translation of the original book, al-Zarī ${ }^{c} a$ ila makārim al-sharī a ("The Path to Virtue") by Rāghib Ișfahānī (d. c. 402/1008-9) written in Arabic in the $10^{\text {th }}$ century. It was translated by Zāfir ibn Shams al-Dīn Hasan in $768 / 1367$. The main subject of the book is ethics and mysticism in seven chapters on taming carnality, particularly by controlling lust and anger. The author employed Quranic verses and hadith as well as poems and proverbs. ${ }^{5}$ Al-Ziari ${ }^{`} a$ has been compared with the Akhlāq-i Nāșirī, which is considered among the most influential didactic works, and sometimes considered even more important. ${ }^{6}$ According to the Kashf al-zunūn, al-Ghazāli praised $a l-\underline{Z} a r i ̄ c a$ and always carried it with him. ${ }^{7}$

The manuscript begins with the ex libris of Bāysunghur's library on fol. 1r, which is embellished with an elaborate pointed shamsa, and reads:

$$
\text { 》برسم خز انة الكتب السّلطان الاعظم و الخاقان الاعدل الاكرم بايسنغر بهادر خان خلداله ملكه؛ }
$$

The first part contains two other sarlauhs. The preface of the first book begins with an adorned sarlauh on fol. 1v, with a white Kufic bismillah on an ultramarine blue (lapis) ground (see fig. 3), which reads:

$$
\text { 《بسم الله الرحمن الرحيم) }
$$

London, 19.1.2015); however, he did not mention it when previously discussing the manuscript (2001, 2005). See also Wright (2012), p. 374, n. 47.

${ }^{5}$ The following article offers a concise introduction on the author and his book: Mīrlauhị (1376/1997): pp. 248-249. For an English translation of the book, see Mohamed (2006).

${ }^{6}$ Khwānsārī (1390/2011): III, p. 198.

${ }^{7}$ Ḥājjī Khalīfa (1360 AH/1940): I, p. 827. 
The second sarlauh appears on fol. $9 \mathrm{v}$ and bears a similar inscription with a white Kufic bismillah on an ultramarine blue (lapis) ground, which reads:

$$
\text { 《بسم الله الرحمن الرحيم و به نستعين «" }
$$

The first colophon on fol. 184r gives the completion date as late Shawwāl 833/July 1430.

$$
\text { ثلثثين و ثمان مايهاب كنوز الوديعه من رموز الذريعه الى مكارم الثريعة فى اواخر شو ال ختم بالخير و الإقبال بعام ثلث و }
$$

\section{Figure 3: sarlauh, fol. 1v, no. 937, Yeni Cami library, Istanbul}

The next part, al-Faraj ba'd al-shidda wa al-ż̄qa ("Relief after Difficulty and Distress"), was originally written in Arabic by Qāż̄i Abū 'Alī Muḥassan ibn 'Alī Tanūkhī, also in the $10^{\text {th }}$ century. It contains stories of the heroic and moral behaviour of people suffering hardships who finally find relief and wellbeing. ${ }^{8}$ According to the scribe, the book was copied from its second Persian translation by Husayn ibn As'ad ibn al-Husayn alDihistānī in the $13^{\text {th }}$ century. No record of the first translation by Muhammad 'Aufĩ has survived to our time. The book begins at fol. 185r, where the second ex libris appears within another exquisite illuminated shamsa. It reads:

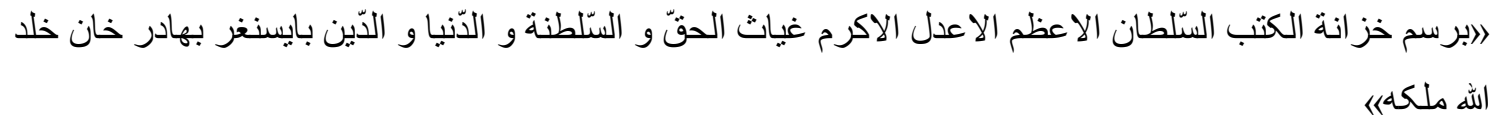

The second shamsa is also pointed (turanj), and is embellished with similar patterns and decorative arabesques.

The preface of the second book (fol. 185v) is adorned with an illuminated sarlauh, with an inscription in white Kufic script:

\footnotetext{
${ }^{8}$ See also Elise Franssen (2010): pp. 64-66, for a description of the author and the work.
} 


$$
\text { 》ذكر الله اعلى و بالبعدكم اولى《) }
$$

The beginning of the body of the second book, al-Faraj ba'd al-shidda wa al-īiqa, is marked by another sarlauh of the same style on fol. 195v. The white Kufic script on lapis ground, introduces the first chapter:

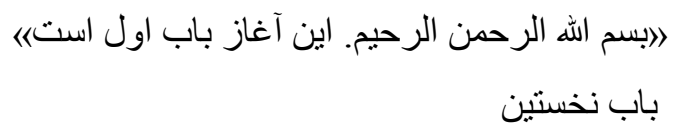

The second colophon appears on fol. $472 \mathrm{v}$, and gives the date of completion as: $18 \mathrm{Rab}^{\mathrm{c}}$ al-ākhir 833/11 January 1430, and the name of the scribe as Sa'd al-Mashhadī.

$$
\begin{aligned}
& \text { >اتم الكتاب الموسوم بفرج بعد الثده بعون الله و حسن توفيقه فى الثامن و العشرين ربيع آخر حجة ثلث و ثلثين و } \\
& \text { ثمان مايه على يد العبد الضعيف النحيف اقل عبيد السلطانى سعد المشهدى غفر الهه ذنوبه و ستر عيوبه آمينه }
\end{aligned}
$$

It is worth noting that the reason why the first colophon gives a later date than the second is obscure. The fact that the name of the scribe only comes at the end of the manuscript suggests that this was the intended order for the combination of the two texts.

\section{Visual features}

As correctly observed by Roxburgh, 'didactic works represented a high proportion of Bāysunghur's library' ${ }^{9}$ This codex is also comprised of two mystic-didactic works, both written in the $10^{\text {th }}$ century. Since they did not lend themselves to being a proper vehicle for illustration, the care given to producing them in such a fastidious manner reveals the importance attached to their content.

Bound in one volume, the beginning of each book is presented with an elaborate shamsa, one on fol. 1r and the other on fol. 185v, as noted above. The Bāysunghuri style of

\footnotetext{
${ }^{9}$ Roxburgh (2005): p. 65 .
} 
illumination is not only echoed in their high precision and meticulous rendering, but also in applying wispy arabesques, which were heavily employed in Bāysunghur's library.

By the year 1427, the ex libris began to serve as emblematic of Bāysunghurī productions and as a mark of a distinctive royal quality. The first example of this is seen at the opening of the Chester Beatty's Gulistān of $\mathrm{Sa}^{\circ} \mathrm{d} \overline{1}, 830 / 1427,{ }^{10}$ which is comparable with the shamsa of al-Z̈arīa a ila makārim al-sharī'a (fig. 4), both in terms of its pattern and design. The motifs and colour palette of the two shamsas are so similar as to suggest that although they were not produced in the same year, they could have been executed by the same hand. In both ex libris, the dedication note is written in a white riq $\bar{a}^{\mathfrak{c}}$ script on green and gold trim. ${ }^{11}$

Figure 4: al-Žarì a ilā makārim al-sharī‘ a, 1430, fol. 1r, no. 937, Yeni Cami Library, Istanbul

The patterns, design and the characteristics of the Kufic script applied to the ornamentation of the sarlauhs are closest to the Bāysunghurī manuscript of the Malik Library (no. 6031), which contains the Shāhnāma of Firdausī and the Khamsa of Nizāimī, copied by Muhammad Muṭahhar, and dated 833/1430 (figures. 5 \& 6). ${ }^{12}$

Figure 5: the Khamsa of Nizāà̄i, 1430, p. 679, no. 6031, Malik National Library, Tehran

\footnotetext{
${ }^{10}$ Reproduced in Wright (2012): p. 114, plate 71.

${ }^{11}$ Another Bāysunghurī shamsa that resembles these two is found in the Kullīyāt of 'Imād al-Dīn Faqīh Kirmāni (834/1431) with regard to the script, design, patterns and the pointed ends of the shamsa. But it is slightly different in colour scheme, as the two aforementioned examples lack the reddish hue (vermilion red). The Kullīyāt of 'Imād, 1431, Elliott 210, Bodleian Library, Oxford. The Tārīkh-i Isfahān of Hamza ibn al-Ḥasan Iṣfahān̄̄, copied by Ja'far Bāysunghuri in 834/1431, now housed in the British Library, London (Or. 2773), also boasts a shamsa of the same sophisticated quality and composition. Albeit here the shamsa is round, without a pointed top and bottom, it includes the vermilion red in its palette. It is worth noting that the riq' $\bar{a}$ script is not written by the same calligrapher in any of the four examples mentioned.

${ }^{12}$ For a comprehensive study of the codex, see Mihan (2016b, in press).
} 
Apart from the initial ornamentation of shamsas and sarlauhs, only changes in the ink colour used for Quranic verses or rubrics enliven the remaining folios.

\section{The Scribe}

As noted above, the colophon of our MS gives the name of the scribe as $\mathrm{Sa}^{\text {' }} \mathrm{d}$ alMashhadī. He was also responsible for copying the Tārīkh-i jahāngushā of 'Atā-Malik Juvaynī, dated Rabī' I 834/December 1430, as stated in the colophon. ${ }^{13}$ That is, he completed two manuscripts within about six months of each other, but to date there is no other record of a text copied by him.

When Ja'far Tabrīzī was appointed as head of the court library-workshop (kitābkhāna) he was responsible not only for supervising courtly projects, but also for reporting the progress of the workshop's activities to the prince. One extant folio of such a regular report is a document, originally written in the form of a scroll, ${ }^{14}$ widely known as the 'Arża-dassht, ${ }^{15}$ in which $\mathrm{Ja}^{\text {'far }}$ itemises the manuscripts in production and the artists or scribes working on them. It does not mention $\mathrm{Sa}^{\prime} \mathrm{d}$ al-Mashhadī in this list of works in progress; however, there is a Maulānā Sa'd al-Dīn. Ja'far refers to the activities connected to Maulānā Sa'd al-Dīn in three cases:

Khwāja 'Ațā, the rulings draftsman (jadval-kash), has finished Maulānā Sa'd al-Dīn's Tārīkh ...

Khwāja 'Ațā has finished the sections of the Gulistān and the sarlauh for the history that Maulānā Sa'd al-Dīn has copied.

\footnotetext{
${ }^{13}$ National Library of Russia, St. Petersburg, PNS. 233, fol. 279v.

${ }^{14}$ Akimushkin (1997): p. 22, discusses the original form of this document before being pasted in the $\mathrm{H}$. 2154 album.

${ }^{15}$ Topkapi Palace Library, Istanbul, H. 2154, fol. 98r. For more information on technical terms used in this document, see Mihan (2016a, in press).
} 
Maulānā Sa'd al-Dīn has finished the lid of the Begum's little chest and one side of it is ready for the final touches. ${ }^{16}$

Thomas Lentz considers that the Tārīkh-i Maulānā Sa'd al-Dīn is problematic and otherwise unknown, though he also refers to Maulānā Sa'd al-Dīn as a 'known calligrapher'. ${ }^{17}$ Thackston, however, believes that, it 'must be the Tārīkh-i Jahāngushāy by Juwaynī copied by Sa'duddin al-Mashhadī in 834 '. ${ }^{18}$

Apart from the light that the two MSS completed by Sa'd al-Mashhadī in 834/1430 might

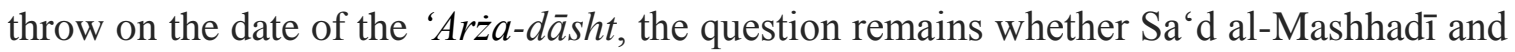
Maulānā Sa'd al-Dīn are indeed one and the same person, and if so, what else can be known about him to indicate his attachment to the court and kitābkhāna of Bāysunghur Mīrzā.

\section{Who was Sa'd?}

$\mathrm{Sa}^{\text {'d }}$ al-Mashhadī does not figure in either contemporary or later sources as a prominent calligrapher. There is only indirect evidence of a homonymous figure. However, in the famous preface to the Safavid album prepared for Bahrām Mīrzā, Dūst Muḥammad refers to two Maulānā Sa'd al-Dīns in the line of prominent calligraphers:

Khwāja 'Abdullāh Șayrafī instructed his nephew Shaykh Muḥammad Bandgīr, who instructed Maulānā Sa'd al-Dīn Tabrīzīi, ...

\footnotetext{
${ }^{16}$ Thackston (2001): p. 43.

${ }^{17}$ Lentz (1985): pp. 150-151, does not mention the Tārīkh-i Jahāngushā, dated 834/1430, among the Bāysunghurī productions; however, he refers to the Tärīkh-i Jahāngushāa, dated 835/1432 in the Keir collection, which contains Bāysunghur's ex libris, but no scribe's name. See also Robinson (1976): p. 296, VII.62 and plate 42 .

${ }^{18}$ Thackston (2001): p. 44.
} 
Maulānā Ma'rūf was a student of Maulānā Sa'd al-Dīn 'Irāqī, who was a student of Pīr Yahyā Șūfī. ${ }^{19}$

In his book on the calligrapher and painters, Gulistān-i hunar, Qāż̄ Aḥmad Qumī does not mention any $\mathrm{Sa}^{\mathrm{c}} \mathrm{d}$ or Sa'd al-Dīn in this lineage, but taking his account of Pīr Yahy $\bar{a}^{20}$ and the date of Sayrafî’s death (d. after 1345-46) ${ }^{21}$ into consideration, neither of the two Sa'd al-Dīns in Dūst Muhammad's preface could be contemporary with Bāysunghur, even disregarding their origins as 'Irāqī or Tabrīzī, rather than Mashhadī.

The only account of $\mathrm{Sa}^{\text {'d }}$ Mashhadī that I have found is in the Tazkira-yi 'Arafāt alāshiqīn (completed in 1024/1615) of Auhadī (b. 1002/1593) - which contains information on almost 3500 poets. Auhadī introduces Sa'd Mashhadī as one of the wellnatured men (khush-țab'ān) of the time and records a couplet by him.

Strangely, in an entry immediately before Sa'd Mashhadī’s, the same couplet is attributed to a homonymous poet called Hāāiz Sa'd. In the words of Auhadī, Hāạiz Sa'd was "a star in the sky of eloquence and oratory". ${ }^{22}$ He then refers to 'the author of Majälis' and repeats Mīr 'Alīshīr Navā'̄̄'s account in the Majālis al-nafāyis, which is the earliest tažkira to mention Hạafiz Sa'd. In this work (completed in 1491), 'Alīshīr Navā'̄̄ (14411501) reports that Ḥāfiz Sa'd was one of the followers of Qāsim Anvār. Sa'd's behaviour caused his expulsion from Anvār's circle of intimates. ${ }^{23}$ That brought him immense affliction and torment, and he died in that state. ${ }^{24}$ Navā' $\overline{1}$ then quotes the same couplet, including a number of other verses, including a riddle on the name of a certain Ahmad

\footnotetext{
${ }^{19}$ Dūst Muhammad (1936): 7. For the translation, see Thackston (2001): p. 8.

${ }^{20}$ Qāżì Aḥmad Qumī (1363/1984): pp. 23-24.

${ }^{21}$ Soucek (1982): pp. 203-205.

${ }^{22}$ Auhadī (1387/2008): III, pp. 1838-39.

${ }^{23}$ See Subtelny (1979-1980), for a pioneering study of 'Alīshīr Navā'̄i. For a more recent analysis of his political life and his cultural, scientific, social and economic works, see Ni'matī Līmā'̄̄ (1393/2015).

24 ‘Alīshīr Navā'̄i (1363/1984): pp. 8-9 and 184-185.
} 
Mīrak. 'Auḥadī adds several more verses; all of these are found in the Dìvān of Ḥāfiz

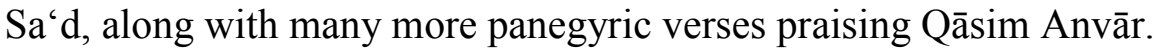

In the Tazkkira-yi Haft Iqlīm, written in 1018/1609, Amīn Aḥmad Rāzī presents Sa'd Gul, as a poet from Shiraz, whose poems are fresh like Kashmir's waters; he records the same verses as those attributed to Ḥāfiz Sa'd in the Majālis al-nafāyis and later by 'Auhadīi.

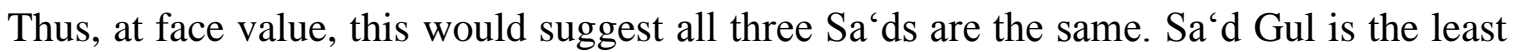
significant figure for the argument. The information about him is repeated in later sources who persist in equating him with Maulānā Sa'd in the Majālis al-Nafa'is. ${ }^{26}$ The best known of these three names is Hâfiz Sa'd; so the question now becomes, can the calligrapher Sa d Mashhadī be equated with the poet Hâafiz Sa ${ }^{\text {‘d }}$ ?

Looking for confirmation of the lines quoted, I consulted two manuscripts of the Divvan of $H \bar{a} f i z S a$ ' $d$, both of which contain all the verses cited by the aforementioned tazkira writers, as well as his other poetical works. One manuscript was certainly made in Shiraz for Pīr Budāq, and it seems evident that this is true of the other also. The earlier of the two is housed in the British Library, Or. 11846 (henceforth, BL) and is beautifully illuminated. The colophon states that the manuscript was copied by Shaykh Maḥmūd Pīr Budāqī, in Șafar of the year 864 (December 1459), at Shiraz. It bears the ex libris of Pīr Budāq (d. 870/1466) that appears in an adorned shamsa. The inscription reads: "For the treasury of the Shadow of God the Beneficent, refuge of the Khaqans of the age, Abu'lFatḥ Pīr Budāq Bahādur Khān, may God support him with victory and favour”.

》برسم خزانه ظل اله المنان ملاذ خو اقين الزمان ابو الفتح بير بوداق بهادر خان ايده الله بالنصر و الاحسان《)

\footnotetext{
${ }^{25}$ Amīn Aḥmad Rāzì (1378/1999): I, p. 215. He adds two other verses not mentioned by Navā'̄i.

${ }^{26}$ The information and verses in Amīn Aḥmad Rāzī are repeated by Khushgū (1756): p. 306. Sunbuhlī (1875): p. 152 and Sadīq (1876): pp. 194-195, copy the information from Rāzī, referring to Sa'd Gul from Shiraz but quoting the single couplet that Navā'î̀ (p. 85) mentions for Maulānā Sa‘d.
} 
The manuscript includes a later illustration on fol. 148r, portraying Pīr Būdāq and his courtiers in a bazm, celebrating the reception of the completed manuscript. ${ }^{27}$ It has been added subsequently (probably in the $19^{\text {th }}$ century) at the end of Sa'd's rubā' $y$ 'y $\bar{a} t$ (quatrains). ${ }^{28}$

The other copy is kept in the Tehran Majlis Library (no. 13159), copied by Mạ̣mūd ibn Muḥammad ibn Maḥmūd Khumārī, dated Shawwāl 864/July 1460 (henceforth, ML). ${ }^{29}$ The note on the shamsa (fol. 1r) is damaged and illegible. On fol.1v, the inscription of the sarlauḥ reads: Dìvān-i Hāfiz Sa'd, with no nisba or indication of his origin. Although the colophon gives no reference to its location, and the patron is not named, it seems certain that this also was made for Pīr Budāq, on account of the date and scribe. According to Bayān̄̄, Khumārī worked as a well-known copyist at the court of Pīr Budāq QaraQoyunlu, in Shiraz. ${ }^{30}$

Both manuscripts contain 185 folios, completed in the same year and probably the same place. Comparing their frontispieces, they also share a similar page layout, illumination motifs and colour scheme in the sarlauh (fig. 7). ${ }^{31}$ Although the BL manuscript is more elaborately illuminated, the vacant spaces in the Majlis manuscript corroborate the idea

\footnotetext{
${ }^{27}$ For the patron and the scribe, see also Robinson (1991): pp. 29-34.

${ }^{28}$ For a comprehensive study of this manuscript, see Barbara Brend (forthcoming). I am grateful to Dr. Brend for sharing her unpublished article and also for her feedback on this paper.

${ }^{29}$ In the library label the author is wrongly identified as Jalāl al-Dīn Sa'd-Allāh Tabrīzī. This probably misled Șidāqat Ḥusaynī, who equates Ḥāfiz Sa 'd with "Jamāl al-Dīn Ḥāfiz Sa 'd Tabrīzī, known as Sa‘dAllāh" in his article on the Dīvān of Ḥāfiz Sa 'd; see Șidāqat Ḥusaynī (1392/2013): pp. 161-178. He refers to Tarbīyat (1234/1853), pp. 181-182, where the same verses of Hāfiz Sa'd and his relations with Qāsim Anvār are associated with Maulānā Jalāl al-Dīn Ḥāfiz Tabrīzī, known as Sa'd-Allāh. The first person to call Ḥāfiz Sa ‘d, Sa‘d-Allāh Tabrīzī is Șabā (1297/1880): pp. 291-292, who refers to the story of Qāsim Anvār and quotes two lines from Navā' '̄. According to Āqā Buzurg Tihrānī (1403/1983, p. 446), this is the source of Tarbīyat's identification of Ḥāfiz Sa 'd with Tabriz.

${ }^{30}$ For other works copied by him, see Bayānī (1363/1984): pp. 873-874.

${ }^{31}$ The digital images of the Dìvān of Ḥăfiz Sa‘d (Or. 11846, British Library, London) are accessible online: http://www.bl.uk/manuscripts/Viewer.aspx?ref=or_11846_fs001r\# (last accessed March 19, 2016).
} 
that it was planned to be adorned in a similar fashion, but was left incomplete for some reason. All these details point to the fact that they were commissioned by the same patron, Pīr Būdāq, who probably encountered Sa'd's Dìvān while in Herat at the time of the Qara-Qoyunlu capture of city in $1458 .{ }^{32} \mathrm{He}$ was the eldest son of Jahānshāh QaraQoyunlu, who came back to Shiraz in 864/1460 after aiding his father to suppress his brother's rebellion in Azarbayjan. ${ }^{33}$ He then ordered the repair and fortification of the city walls, ${ }^{34}$ before rebelling himself against his father. Eventually, he had to escape to Shūshtar, when Jahānshāh sent an army to repel him in the spring of 865/1461, and then sent him to Baghdad the following year. ${ }^{35}$ Jahānshāh appointed Pīr Budāq's brother, Mīrzā Yūsuf, to the governorship of Shiraz. ${ }^{36}$ This would probably explain the incomplete decoration of the Majlis manuscript, which was transcribed around seven months after the BL manuscript and on the eve of Pīr Budāq's revolt.

Another Dīvān housed in the Central Library of the University of Tehran (no. 225/2), also contains most of Sa'd's verses; however, this time in the name of Sa'd Bukhārī (undated, c. $16^{\text {th }}$ century). This copy includes only 360 lines of his poems, while the other two editions have more than 4500 lines. ${ }^{37}$ The only tazkkira with an account of Hāfiz Sa'd Bukhārī is the Tažkira-yi Nașrābādī (1072/1662), which just mentions two riddles. ${ }^{38}$

Concerning the poetry, all the lines attributed to ' $\mathrm{Sa}^{\text {' }} \mathrm{d}$ ' in the scattered biographical dictionaries are found in his complete Div $\bar{a} n$. This suggests that they all represent the

\footnotetext{
${ }^{32}$ For a concise account of Pīr Budāq, see Jalālī (1385/2004): pp. 119-121.

${ }^{33}$ Khwāndamīr (1353/1974): IV, p. 75.

${ }^{34}$ Fasā'̄ì (1367/1988): I, 347; II, p. 902.

${ }^{35}$ Budāq Munshī (1378/1999): pp. 67-68; Vālih Iṣfahānī (1379/2000): p. 710.

${ }^{36}$ Khwāndamīr (1353/1974): IV, p. 85.

${ }^{37}$ Āqā Buzurg Tihrānī (1403/1983, vol. 9, part 2, p. 446) referring to this manuscript, naturally assumes Hâafiz Sa'd was from Bukhara, and draws attention to the confusion between Ḥăfiz Sa'd and the Sa'd-Allāh Tabrīzī, mentioned by Șabā (1297/1880): pp. 291-292 and Tarbīyat (1234/1845): p. 181. See above note 29.

${ }^{38}$ Nașrābādī Iṣfahanī (1378/1999): p. 756.
} 
same poet, Hāāiz Sa'd, who lived in Herat, was once Qāsim Anvār's intimate, and therefore was contemporary with Prince Bāysunghur.

Figure 7: Dīvān of Hāfiz Sa‘d, 864/1460, fol. 2v, no. 13159, Majlis Library, Tehran.

The title 'Hāfiz', was a common epithet for scribes. In the case of Sa'd, it can be construed from the dedication shamsa of the BL's Dìvann, that he was a reciter of the Quran. The inscription describes him as: 'șāḥib al-furqān' (master in the Quran) almushtahar bi (known as) Hāāiz Sa‘d.

Being a famous poet and a Quran reciter, we could expect him to be well versed in calligraphy as well. It is hardly necessary to recall the strong interconnection between poets and calligraphers, and that most calligraphers also wrote poetry, to which they usually referred as 'li muharririhi'.

Thomas Lentz discusses how Timurid artists, like their Safavid counterparts, often possessed considerable literary talents that may have been expected at this elite social level. ${ }^{39}$ Such a connection was indeed conspicuous at Bāysunghur's court, judging from contemporary and later historical sources. The Jung-i marās $\underline{s}$ that contains eulogies on Bāysunghur's death is a good example: it shows that not only his court poets, but also the artists who were involved in the royal projects of the kitābkhāna, expressed their loss via poetry, one way or another (fig. 8). ${ }^{40}$ That being so, and taking 'Auhadī's entries on Sa'd Mashhadī and Hāfiz Sa'd into consideration, it could be surmised that the well-known poet was the scribe of the two Bāysunghurī codices. ${ }^{41}$

\footnotetext{
${ }^{39}$ Lentz (1985): p. 151.

${ }^{40}$ The Jung-i marās $\underline{\imath}$ begins with seven pages of lament by Ja'far. This implies his superior position as the head of the library as well as being a testimony to his knowledge of literature and outstanding quality as a poet. Jung-i marās $\underline{1}$, 837/1434, scribe: Aẓhar, no. 2967, the Central Library of Tabriz.

${ }^{41}$ Roxburgh (2005): p. 107, mentions a scribe named Ḥāfiz Sa‘d Shīrvānī in association with signed specimens in the first part of the calligraphy album prepared for Bāysunghur (B. 411, Topkapi Palace
} 
Figure 8: Jung-i marās̆ $\underline{l}, 1434$, fol. 2r, no. 2967, Central Library, Tabriz.

To elaborate this theory, we need to look back a few years. After Aḥmad Lur's unsuccessful regicide attempt on Shāhrukh, and regarding his connection with Qāsim Anvār - of whom Shāhrukh was wary due to his fame and the large number of followers he had gained in Herat - it was a justified pretext to execute or exile many sufis, among whom was Qāsim Anvār himself. ${ }^{42}$ Eventually, Bāysunghur exiled him from Herat in $830 / 1427 .^{43}$

According to the aforementioned tažkiras, Qāsim Anvār ordered the destruction of Sa'd's chamber and the removal of its soil, before the miserable poet's expulsion. Be it the case that the well-known poet, Hāfiz Sa'd, was the same as the calligrapher, Sa'd (al-Dīn) Mashhadī, it is plausible to imagine him joining the court library after his exclusion from Anvār's circle. The hostile attitude of Bāysunghur towards Qāsim Anvār reinforces the possibility of his offering his patronage to the deprived poet. A closer investigation of Sa'd's poems provides more evidence to support this theory.

\section{Riddles}

Writing riddles became very popular in the $15^{\text {th }}$ century. 'Alīshīr Navā'̄̄ records a number of riddle-writers in his tažkira, among whom Maulānā Bad̄̄‘̄ì, 'Alī Yazdī and

Library), along with other well-known calligraphers who worked for Bāysunghur. Unfortunately, he does not give a full reference, nor reproduce an image. Although it is not logical to think that a scribe would sign his own name with two different nisbas - Shīrvānī and Mashhadī - if the signature was added subsequently, the nisba Shîrvānī would merely confirm the remarkable uncertainties regarding his origin (variously Mashhadī, Shīrāzī, Bukhārī, Tabrīzī, and now Shīrvān̄i), if indeed they are all one and the same person.

${ }^{42}$ See Fașịh Khwāfĩ (1386/2007): II, p. 86; and Khwāndamīr (1353/1974): III, p. 617 and IV, pp. 10-11.

${ }^{43}$ For more information about his life and shrine, see Daulatshāh Samarqandī (1382/2003): pp. 346-352. For his attraction to the Hurūfĩ doctrine, see Șafã (1369/1990): IV, pp. 252-64; for a thorough investigation of the attempt on Shāhrukh, see Binbaş (2013): esp. pp. 402-404. 
Jāmī have treatises on the principles of riddles. ${ }^{44}$ The Risāla-yi mufradāt dar fann-i ти 'mmā is a treatise by Navā' $\overline{1}$ to teach the skills of writing and decoding riddles from basics. ${ }^{45}$ For instance, a riddle from the Hulal-i muțarraz of 'Alī Yazdī would clarify how to interpret and decode them:

$$
\text { در شَت باسى عدد كار تمام است ولى در آن بين بانثد }
$$

With the number ('adad) 60, the work is done, but

only if 1 and 30 come in between

In the Abjad writing system, each symbol stands for a consonant and is related to a number.

60 stands for w

1 stands for الف

30 stands for $J$

Thus, according to the riddle, placing $60=\omega$ beside will give the answer, provided that is put in between, which makes س عد ال

The final chapter in Sa'd's dīvān is dedicated to Mu'ammìyat (riddles). It comprises the folios from $148 \mathrm{r}$ to $185 \mathrm{r}$ in ML and $148 \mathrm{v}$ to $185 \mathrm{v}$ in BL. In Sa'd's Mu 'ammīyāt section, each name is followed by a single couplet, which contains the clue to the person's identity. The names are very similar in both manuscripts; however, in some cases trivial changes can be found.

The key names featuring in this chapter make their connection to Bāysunghur's court certain. The characters from the house of Timur who have at least one riddle written for them are as shown in the table (the names are given as they appear in the BL's copy).

\footnotetext{
${ }^{44}$ Sām Mīrzā Șafavī (1316/1927): p. 86.

${ }^{45}$ For riddle writing in the $15^{\text {th }}$ century, see Yarshater (1383/2004): pp. 239-243.
} 


\begin{tabular}{|l|l|l|l|}
\hline \multicolumn{1}{|c|}{ Political figure } & \multicolumn{1}{|c|}{ name in the riddle } & \multicolumn{1}{c|}{ ML } & \multicolumn{1}{c|}{ BL } \\
\hline Shāhrukh & Shāhrukh Bahādur Khan & $176 \mathrm{v}$ & $177 \mathrm{r}$ \\
\hline \multirow{3}{*}{ Bāysunghur } & Bāysunghur Bahādur & $168 \mathrm{v}$ & Missing \\
\cline { 2 - 4 } & Bāysunghur & $175 \mathrm{r}$ & - \\
\cline { 2 - 4 } & Bāysunghur Khusrau & - & $176 \mathrm{r}$ \\
\hline Ulugh Beg & Ulugh Beg Bahādur & $183 \mathrm{r}$ & $183 \mathrm{v}$ \\
\hline $\begin{array}{l}\text { 'Alā' al-Daula } \\
\text { (Bāysunghur's son) }\end{array}$ & 'Alā' al-Daula & $148 \mathrm{r}, 175 \mathrm{v}, 183 \mathrm{v}$ & $148 \mathrm{v}, 176 \mathrm{v}, 184 \mathrm{r}$ \\
\cline { 2 - 4 } & Mīr'Alā' al-Daula & $182 \mathrm{v}$ & $183 \mathrm{r}$ \\
\hline $\begin{array}{l}\text { Sūrghatmīsh } \\
\text { (Shāhrukh's son) }\end{array}$ & Rukn al-Dīn & $165 \mathrm{v}$ & $166 \mathrm{r}$ \\
\hline
\end{tabular}

There are many other names that cannot be definitively identified, but are very probably connected to Bāysunghur's court. Several are identical to the artists involved in Bāysunghur's court projects, according to the 'Arża-dāsht. The table below provides a comparison between the names for which a riddle is written and the ones mentioned in the 'Arża-dāsht.

\begin{tabular}{|c|c|c|c|}
\hline 'Ariza-dāsht & $\overline{D \bar{v}} \bar{a} n$ of $\mathrm{Sa}^{6} \mathrm{~d}$ & ML & BL \\
\hline \multirow[t]{2}{*}{ Amīr Khalīl } & Khwāja Khalīl & $149 \mathrm{r}$ & $\overline{149 v}$ \\
\hline & Khalil darwish & $175 \mathrm{r}, 177 \mathrm{r}$ & $175 \mathrm{v}$ \\
\hline \multirow[t]{2}{*}{ Maulānā 'Alī } & 'Alī & 148r, 172r, 179r & $148 \mathrm{r}, 156 \mathrm{r}, 172 \mathrm{v}$ \\
\hline & Mīr 'Alī & $\begin{array}{l}\text { 167r, 160r, 157r, } \\
150 \mathrm{r}\end{array}$ & $150 \mathrm{v}, 157 \mathrm{v}, 167 \mathrm{v}$ \\
\hline \multirow[t]{3}{*}{ Khwāja Ghīyāṣ al-Dīn } & Ghīyās al- Dīn & $155 \mathrm{r}$ & $155 \mathrm{v}$ \\
\hline & Ghīyāạ & $161 \mathrm{r}$ & $161 \mathrm{v}$ \\
\hline & Mīr Ghīyās & $164 v$ & $165 \mathrm{r}$ \\
\hline Maulānā Shihāb & Shihāb & $165 \mathrm{v}$ & $166 r$ \\
\hline Maulānā Qavām al-Dīn & Qavām al-Dīn & $158 \mathrm{v}$ & $159 \mathrm{v}$ \\
\hline
\end{tabular}




\begin{tabular}{|c|c|c|c|}
\hline & Ustād Qavām al-Dīn & $180 \mathrm{r}$ & Missing \\
\hline Maulānā Shams & Shams & $\begin{array}{l}171 \mathrm{r}, 182 \mathrm{v}, \\
151 \mathrm{r}, 158 \mathrm{v}\end{array}$ & $\begin{array}{l}171 \mathrm{v}, 183 \mathrm{r}, 151 \mathrm{v}, \\
159 \mathrm{r}\end{array}$ \\
\hline Hājjjī Maḥmūd & Mīr Maḥmūd & $181 \mathrm{v}, 155 \mathrm{r}$ & $182 \mathrm{r}, 155 \mathrm{v}$ \\
\hline Khwāja Maḥmūd & Khwāja Maḥmūd & $173 r$ & $174 \mathrm{r}$ \\
\hline \multirow[t]{2}{*}{ Khwāja 'Ațāa } & 'Atā & $\begin{array}{l}151 \mathrm{v}, 165 \mathrm{r}, \\
175 \mathrm{v}\end{array}$ & $152 \mathrm{r}, 165 \mathrm{v}, 176 \mathrm{r}$ \\
\hline & Khwāja 'Atā & $161 \mathrm{r}$ & $162 \mathrm{r}$ \\
\hline \multirow[t]{3}{*}{ Maulānā Sa'd al-Dīn } & $\mathrm{Sa}^{6} \mathrm{~d}$ & 158r, 177r, 178r, & $158 \mathrm{v}, 177 \mathrm{v}, 178 \mathrm{v}$ \\
\hline & Sa'd al-Dīn & $\begin{array}{l}173 \mathrm{v}, 159 \mathrm{v} \\
\text { (twice), } 172 \mathrm{v}\end{array}$ & $160 v, 173 r, 174 r$ \\
\hline & Maulānā Sa'd al-Dīn & $174 v$ & $175 \mathrm{r}$ \\
\hline Maulānā Quțb & Quțb & $\begin{array}{l}165 \mathrm{r}, 164 \mathrm{r}, \\
175 \mathrm{v}, 166 \mathrm{v}\end{array}$ & $\begin{array}{l}165 \mathrm{v}, 164 \mathrm{v}, 176 \mathrm{v}, \\
167 \mathrm{r}\end{array}$ \\
\hline Maulānā Muḥammad & Muțahhar & $163 \mathrm{r}, 175 \mathrm{v}$ & $164 \mathrm{r}, 176 \mathrm{r}$ \\
\hline Muțahhar & \begin{tabular}{|l} 
Mīr Muțahhar \\
\end{tabular} & $174 \mathrm{v}, 172 \mathrm{r}$ & $172 \mathrm{v}, 175 \mathrm{v}$ \\
\hline Khwāja 'Abd al-Raḥīm & \begin{tabular}{|c|} 
'Abd al-Raḥīm \\
\end{tabular} & $181 \mathrm{r}, 152 \mathrm{v}$ & $181 \mathrm{v}, 153 \mathrm{r}$ \\
\hline Hājjjī & Hājjī & $163 r, 161 r$ & $163 \mathrm{v}, 161 \mathrm{v}$ \\
\hline Khatā'̄ & $\begin{array}{l}------- \\
\end{array}$ & $\overline{------}$ & $\begin{array}{l}------ \\
\end{array}$ \\
\hline 'Abd al-Salām & 'Abd al-Salām & $151 \mathrm{r}, 160 \mathrm{v}$ & $151 \mathrm{v}, 161 \mathrm{v}$ \\
\hline Ustād Sayf al-Dīn & Sayf al-Dīn & missing & $161 \mathrm{r}$ \\
\hline Mīr Daulatyār & $\begin{array}{ll}----- \\
\end{array}$ & ----- & $\begin{array}{ll}----- \\
\end{array}$ \\
\hline Khwāja Mīr Ḥasan & Mīr Ḥasan & $153 r, 163 r$ & $163 \mathrm{v}, 153 \mathrm{v}$ \\
\hline Mīr Shams al-Dīn & \begin{tabular}{|l} 
Shams al-Dīn \\
\end{tabular} & $155 \mathrm{r}, 179 \mathrm{r}$ & 156r, 180r \\
\hline Ustād Daulat Khwāja & $\begin{array}{ll}------ \\
\end{array}$ & --------- & |------------ \\
\hline $\mathrm{Ja}^{6} \mathrm{far}$ & Mīr Ja'far & $157 \mathrm{r}, 168 \mathrm{v}$ & $157 \mathrm{v}, 169 \mathrm{v}$ \\
\hline
\end{tabular}


As the table clearly illustrates, only three out of the 22 names of the 'Arża-dāsht are not covered in the $M u$ 'ammìyatt. Although some names were very common, like 'Alī, other specific tributes like Ustād Qavām al-Dīn leave no room for doubt.

There are also riddles on the names of other known characters, such as: Fașịh al-Dīn (probably Bāysunghur's historian, Fașịh Khwāfĩ), 'Abd al-Qādir (probably the famous musician and singer 'Abd al-Qādir Marāghī), Shihāb al-Dīn (probably the famous chronicler, Ḥāfiz Abrū), Maulānā 'Abd al-Rahmmān (very likely the famous poet 'Abd alRaḥmān Jāmī), and so on. The data presented in these tables leave no doubt about Ḥāfiz Sa'd's presence at Bāysunghur's court.

As noted above, 'Alī Yazdī (d. 1454), the author of the Zafarnāma, was a leading and prominent riddle-writer. He completed his treatise, al-Hulal al-mutarraz fi al-mu'ammā wa al-lughaz, in 832/1429 and dedicated it to Abu'l-Fath Ibrāhīm Sultān. ${ }^{46}$ It is a complete book on the subject, with many riddles on different names, some of which can be connected to contemporary figures (fig. 9). Apart from his own name, Sharaf, which is used both as his takhallus (pen name) and the subject for many riddles, he has verses for the names of both $\mathrm{Sa}^{\text {' }} \mathrm{d}$ and $\mathrm{Sa}^{\text {' }} \mathrm{d}$ al-Dīn, as we have seen.

\section{Figure 9: al-Hulal al-muțarraz, 1068/1658, fol. 56r, F. 2612/1, Melli Library, Tehran}

Similarly, Sa'd's mu 'ammīyāt include riddles for his own name too: Sa'd and Sa'd alDīn; but the significant point is that he also presents several riddles in name of 'Alī Yazdī, as: Sharaf al-Dīn 'Alī, Sharaf al-Dīn, and Sharaf. This suggests first, that it was usual for authors to refer to themselves and secondly, that they could do so under more than one name. Although it may appear an insubstantial assumption that $\mathrm{Sa}^{\mathrm{c}} \mathrm{d}$ and $\mathrm{Sa}^{\mathrm{c}} \mathrm{d}$ al-Dīn are the same and also refer to the author (Hafiz Sa'd) - Sa'd al-Dīn after all is not an uncommon name - there is no doubt about the different references to the same 'Alī

\footnotetext{
${ }^{46}$ Shamīlpūr et al. (1394/2015), have recently published a study on the stylistic and literary aspects of the Hulal-i muțarraz dar mu 'ammā va lughaz.
} 
Yazdī. Furthermore, it seems as though an exchange was taking place between the two outstanding riddle-writers of the time, or even a kind of intellectual competition between the courts of the two Timurid brothers. ${ }^{47}$

\section{Conclusion}

This paper has identified a previously neglected manuscript issuing from the atelier of Bāysunghur Mīrzā, significant partly for the evidence of its original binding dedicated to the prince, and partly as providing another example of the calligraphy of the enigmatic Sa'd Mashhadī.

The evidence presented suggests rather strongly that the 'Maulānā Sa'd al-Dīn' of the 'Arża-dāsht was the same as Sa'd Mashhadī, who was the scribe of the two codices: the Yeni Cami MS, and the Tārīkh-i jahāngushā of 'Ațā Malik Juvaynī, both transcribed in the year 1430. In view of the coincidence of dates and Sa 'd Mashhadī's certain activity as a scribe in the atelier at exactly this period, he can also be identified with the contemporary poet Ḥāfiz Sa $\mathrm{Sa}^{d}$, and perhaps rather better known for his poetry than as a scribe - though as a hăfiz (or khatīb) he could certainly have been skilled in calligraphy as well.

Investigating the Divvān of Haafiz Sa'd revealed the connection between the poet and Bāysunghur Mīrzā's court. Ḥāfiz Sa'd, a devotee of the Sufi leader of his time, Qāsim Anvār, was very probably the same figure as the scribe, Sa'd Mashhadī. He could have sheltered under the protection of Prince Bāysunghur after Anvār turned him away and had his chamber destroyed completely. This must have taken place before Anvar's exile from Herat in 1427, the latest date for Sa 'd's joining Bāysunghur's court/workshop. This

\footnotetext{
${ }^{47}$ Among Shāhrukh's sons, Bāysunghur and Ibrāhīm Sulțān were always in competition to have the top artists, poets and musicians. The story of Yūsuf Andakānī provides an obvious example. See Daulatshāh Samarqandī (1382/2003): pp. 350-351.
} 
would also help to explain why he does not feature prominently in the tazkiras as a calligrapher.

Although the completion date of the Dīvān of Hāfiz Sa'd is not known, the interconnection of his riddles with 'Alī Yazdī's, completed in 832/1429, suggests an approximate date for the completion of the Dìvān of Hâfiz Sa'd; and together with the dates given in the colophons of the two codices transcribed by him (1430), suggest that he was definitely active around $1427-1430$.

\section{Bibliography}

\section{Manuscripts}

'Arża-dāsht, Ja'far Tabīzī, undated, H. 2154, Topkapi Palace Library, Istanbul.

Bāysunghur Calligraphy Album, undated, B. 411, Topkapi Palace Library, Istanbul.

Chahār Maqāla, Niẓāmī 'Arużī Samarqandī, 835/1431, scribe: al-Sultānī, no. 1954, Museum of Turkish and Islamic Art, Istanbul.

Dìvān, Ḥāfiz Sa‘d, 864/1459, scribe: Shaykh Maḥmūd Pīr Budāqī, Or. 11846, British Library, London.

Dīvān, Ḥāfiz Sa‘d, 864/1460, scribe: Maḥmūd ibn Muḥammad ibn Mạ̣mūd Khumārī, no. 13159, Majlis Library, Tehran.

Gulistān, Sa'd̄̄, 830/1427, scribe: Ja'far Bāysunghurī, P. 119, Chester Beatty Library, Dublin.

Al-Hulal al-muțarraz fi al-mu'ammā wa al-lughaz, Sharaf al-Dīn 'Alī Yazdī, 1068/1658, scribe: Ibrāhīm, F. 2612/1, Melli Library, Tehran.

Jung-i marās̄ī, 837/1434, scribe: Aẓhar, no. 2967, Central Library, Tabriz. 
Kalīla-u Dimna, Naṣr Allāh Munshī, 833/1429, scribe: Muhạmmad ibn Ḥusām (known as) Shams al-Dīn al-Bāysunghurī, R. 1022, Topkapi Palace Museum, Istanbul.

Kalīla-u Dimna, Nașr Allāh Munshī, 834/1431, scribe: Ja'far al-Bāysunghurī, H. 362, Topkapi Palace Museum, Istanbul.

Kullīyāt, 'Imād al-Dīn Faq̄̄h Kirmānī, 834/1431, Elliott 210, Bodleian Library, Oxford.

Nașāyihh-i Iskandar, 829/1426, scribe: Ja'far Bāysunghurī, Ar. 4183, Chester Beatty Library, Dublin.

Shāhnāma of Firdausī; and Khamsa of Nizāāī, 833/1430, no. 6031, Malik National Library, Tehran.

Tārīkh-i Jahāngushā of Juvaynī, 834/1430, PNS. 233, National Library of Russia, St. Petersburg.

Tārīkh-i Jahāngushā of Juvaynī, 835/1430, VII. 62, Keir Collection, London.

Tārīkh-i Ișfahān, Ḥamza ibn al-Ḥasan Iṣfahānī, 834/1431, scribe: Ja ‘far Bāysunghurī, Or. 2773, British Library, London.

Tārīkh-i Jahāngushā, 'Ațā Malik Juvaynī, 833/1430, scribe: Sa'd al-Mashhadī, PNS. 233, National Library of Russia, St. Petersburg.

Tārīkh-i Jahāngushāa, ‘Ațā Malik Juvaynī, 835/1433, Keir collection, VII. 62.

(Tarjuma-yi) Tārīkh-i Tabarī, Abū 'Alī Bal'amī, 833/1430, scribe: Quṭb al-Dīn ibn Ḥasan Shāh al-Kirmān̄̄, PNS. 49, National Library of Russia, St. Petersburg.

al-Žarī'a ilā makārim al-sharî̀ a by Rāghib Ișfahān̄i; and tarjuma-yi al-Faraj ba'd alshidda wa al-ż̄iqa by Ḥusayn Dihistānī, 833/1430, scribe: Sa ‘d al-Mashhadī, no. 937, Yeni Cami Library, Istanbul. 


\section{Printed works}

M.R. Ādamīyyat, Dānishmandān va sukhan-sarāyān-i Fārs, 4 vols. (Tehran, 1336/1957).

O.F. Akimushkin, “The Library-Workshop (kitābkhāna) of Bāysunghur-Mīrzā in Herat”, Manuscripta Orientalia, 3, 1 (Mar. 1997), pp. 14-24.

‘Alīshīr Navā’̄i, Majālis al-nafāyis, ed. 'A. A. Hekmat (Tehran, 1363/1984).

Amīn Aḥmad Rāzī, Tažkira-yi Haft Iqlīm, ed. J. Fāżil, 3 vols. (Tehran, 1378/1999).

Āqā Buzurg Tihrānī, al-Žarī'a ila tașānīf al-shī'a, 26 vols. (Beirut, AH 1403/1983).

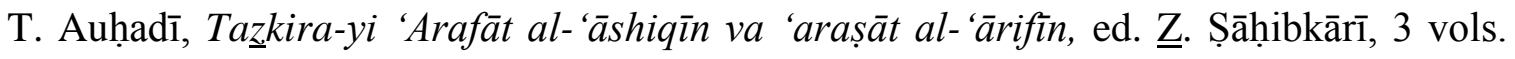
(Tehran, 1387/2008).

M. Bayān̄̄, Aḥvāl va ās $\underline{a} r-i$ khushnivīsān (Tehran, 1363/1984).

I. E. Binbaş, "The anatomy of a regicide attempt: Shāhrukh, the Hurūfīs, and the Timurid intellectuals in 830/1426-27", Journal of the Asiatic Society, third series 23, 3 (July 2013), pp. 391-428.

B. Brend, "Illumination and a problematic picture in a Divan of Hafiz-i Sa'd for Pir Budaq Qara Quyunlu”, (forthcoming).

Budāq Munshī, Javāhir al-akhbār, ed. M. Bahrām Nizhād (Tehran, 1378/1999).

Daulatshāh Samarqandī, Tažkirat al-shu 'arā', ed. E. G. Brown (Tehran, 1382/2003).

Dūst Muḥammad, A Treatise on Calligraphists and Miniaturists, ed. M. 'Abdullāh Chagatai (Lahore, 1936).

Ḥ. Fasā'̄i, Fārs-nāma-yi Nāṣirī, ed. M. Rastgār Fasā'̄ī (Tehran, 1367/1988).

Fașịh Khwāfī, Mujmal-i Faṣịḥ̄, ed. M. Nājī Nașrābādī (Tehran, 1386/2007). 
E. Franssen, "A magribī copy of the Kitāb al-faraj ba'd ašššidda, by the 'Irāqī quạdī alTanūhī. Study of a manuscript of Liège University (Belgium)", Journal of Islamic Manuscripts, 1, 1 (2010), pp. 61-78.

Ḥàjjī Khalīfa (HaCi Halife), Kashf al-ẓnūn 'an asāmī al-kutub wa al-funūn (Istanbul, $1360 \mathrm{AH} / 1940)$.

N. Jalāl̄̄, "Pīr Budāq", in Dāyirat al-ma 'ārif-i buzurg-i Islamī (Tehran, 1385/2004), vol. 14, pp. 119-121.

M.Ḥ. Khān, Sham 'i Anjuman, ed. M. 'A. Khān (Bombay, 1293/1876).

‘A. Khayyāmpūr, Farhang-i sukhanvarān, 2 vols. (Tehran, 1368-72/1990-94).

B.D. Khushgū, Safina-yi khushgū, ed. S. K. Așghar (Tehran, 1389/2010).

M.B. Khwānsārī, Raużāt al-jannāt fi ahvoāl al- 'ulamā' wa al-sādāt, 8 vols. (Tehran, 1390/2011).

Khwāndamīr, Habīb al-sīyar, ed. M. Dabīr Sīyāqī, 4 vols. (Tehran, 1353/1974).

T.W. Lentz, "Painting at Herat under Bāysunghur ibn Shah Rukh", unpublished PhD dissertation (Harvard University, 1985).

K.R. Martin, The Miniature Painting and Painters of Persia, India and Turkey from the 8th to the I8th Century, 2 vols. (London, 1912).

S. Mihan, "On the term keshti in the Baysonghori 'Arzeh-dasht", Iran, LIV (2016a): in press.

S. Mihan, "The Baysunghuri Manuscript in the Malek National Library", Shahnama Studies III, ed. G. van den Berg and C. Melville (Leiden, 2016b): in press.

S.A. Mīrlauhīi, "Mu'arrifî-yi Kitāb”, Mīrāṣ-i Jāvīdān, 19-20 (1376/1997), pp. 248-249. 
Y. Mohamed, The Path to Virtue: the Ethical Philosophy of al-Raghib al-Isfahani, an annotated translation with critical introduction (Malaysia, 2006).

M.T. Naṣrābādī Ișfahanī, Tažkira-yi Nașrābādī, ed. M. Nājī Naṣrābādī (Tehran, 1378/1999).

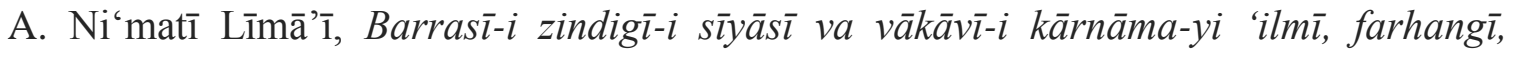
ijtimā 'c̀ va iqtiṣādì-i Amīr 'Alīshīr Navā' '̄ (Mashhad, 1993/2015).

B.W. Robinson, Fifteenth Century Persian Painting. Problems and issues (New York \& London, 1991).

B.W. Robinson, Islamic Painting and the Arts of the Book. The Keir Collection (London, 1976).

D.J. Roxburgh, "Bāysunghur's Library: Questions Related to its Chronology and Production.” Journal of Social Affairs, 18, 72 (2001), pp. 11-39.

D.J. Roxburgh, The Persian Album, 1400-1600 (Yale, 2005).

M.M. Șabā, Tažkira-yi Rūz-i Raushan (Kolkata, AH 1297/1880).

Z. Șafā, Tārīkh-i Adabīyāt dar İrān, 4 vols. (Tehran, 1369/1990).

Sām Mīrzā Șafavī, Tuḥfa-yi Sāmī (Tehran, 1316/1927).

H. Shamīlpūr et al. "Barrasī-yi muhtavā'̄i va sabkī-yi nuskha khatțî̀-yi Hulal-i muṭarraz dar mu'ammā va lughaz", Sabk-shināsī-yi nażm-u nașr-i Fārsī (Bahār-i Adab), 24 (1394/2015), pp. 113-128.

S.R. Șidāqat Ḥusayn̄̄, "Ḥāfiz Sa‘d Tabrīz̄̄", Payām-i Bahāristān, 19 (Tehran, 1392/2013), pp. 161-178.

P.P. Soucek, ““Abdallāh Șayrafî”, Encyclopaedia Iranica, vol. I, fasc. 2 (1982), pp. 203205. 
M.E. Subtelny, “Alī Shīr Navā'̄̄: Bakhsī and Beg”, Harvard Ukrainian Studies, 3-4 (1979-1980), pp. 797-807.

M.D. Sunbuhli, Tazkkira-yi Husaynī (Lucknow, 1292/1875).

M. ‘A. Tarbīyat, Danishmandān-i Azarbāyjān (Tabriz, 1234/1845).

W.M. Thackston, A Century of Princes: Sources on Timurid History and Art (Cambridge, Mass., 1989).

Vālih Iṣfahānī, Khuld-i Barīn, ed. H. Muḥaddis (Tehran, 1379/2000).

E. Yarshater, Shi 'r-i Fārsī dar 'Ahd-i Shāhrukh (Tehran, 1383/2004). 

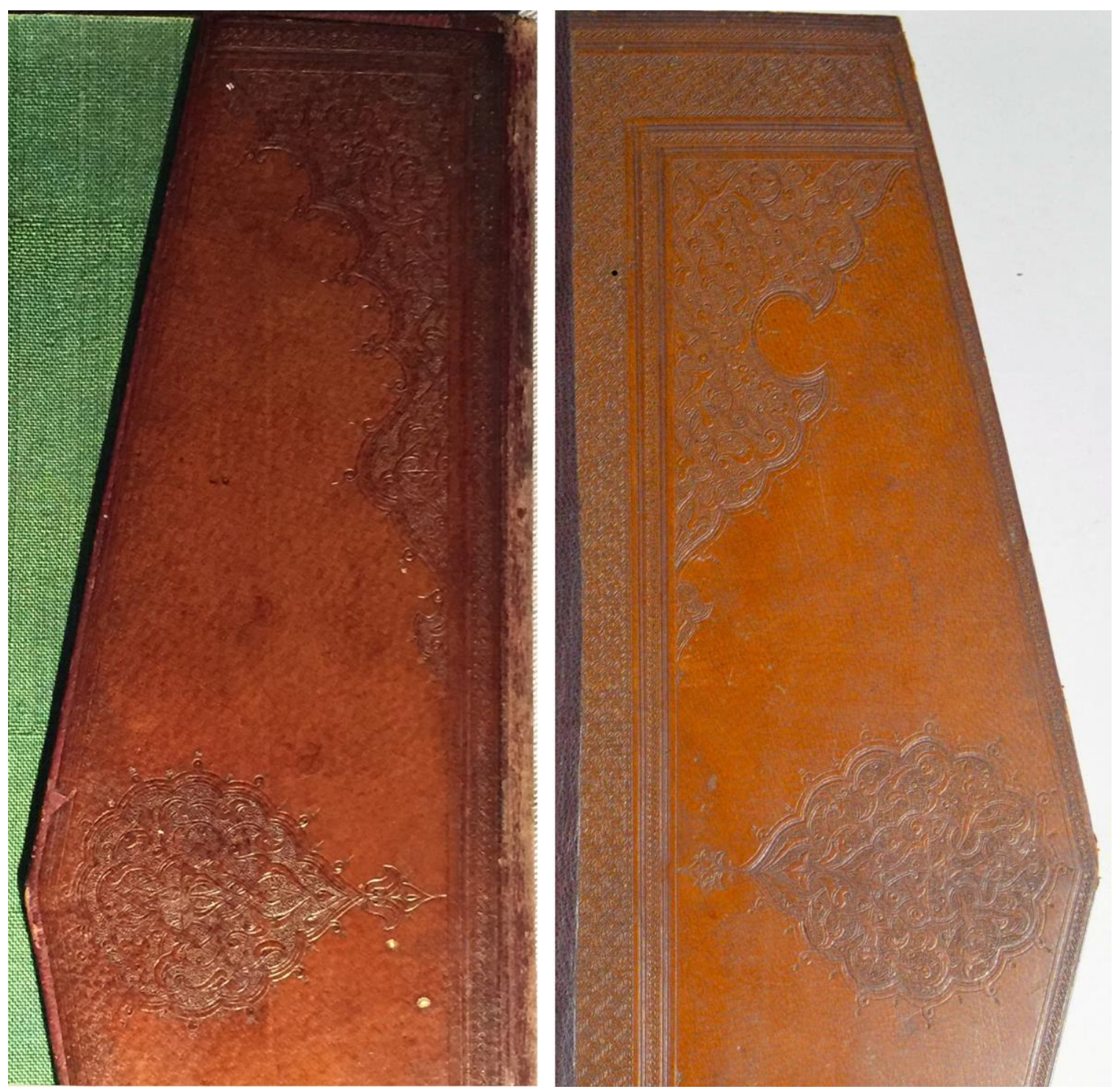

Fig. 1 


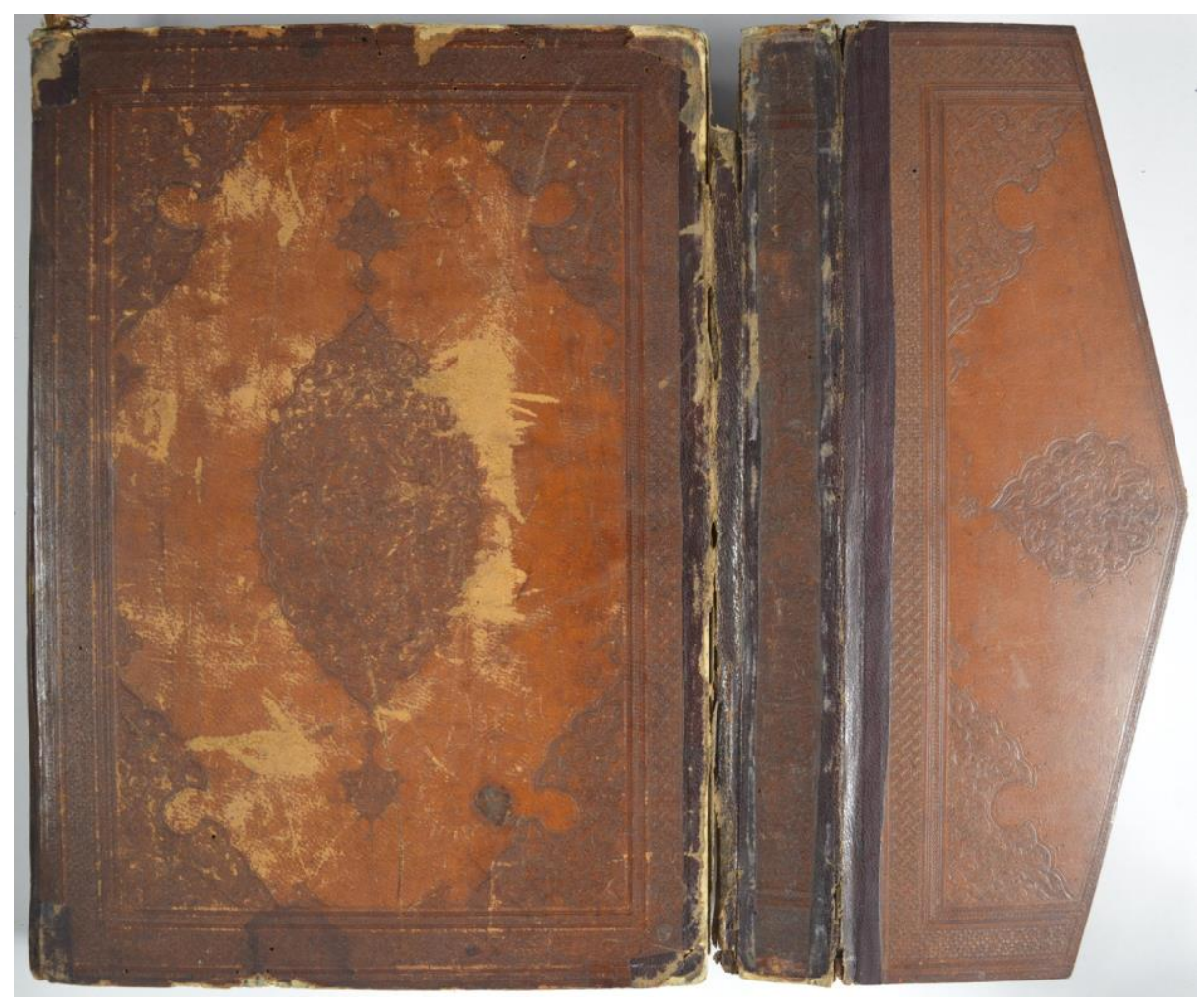

Fig. 2 


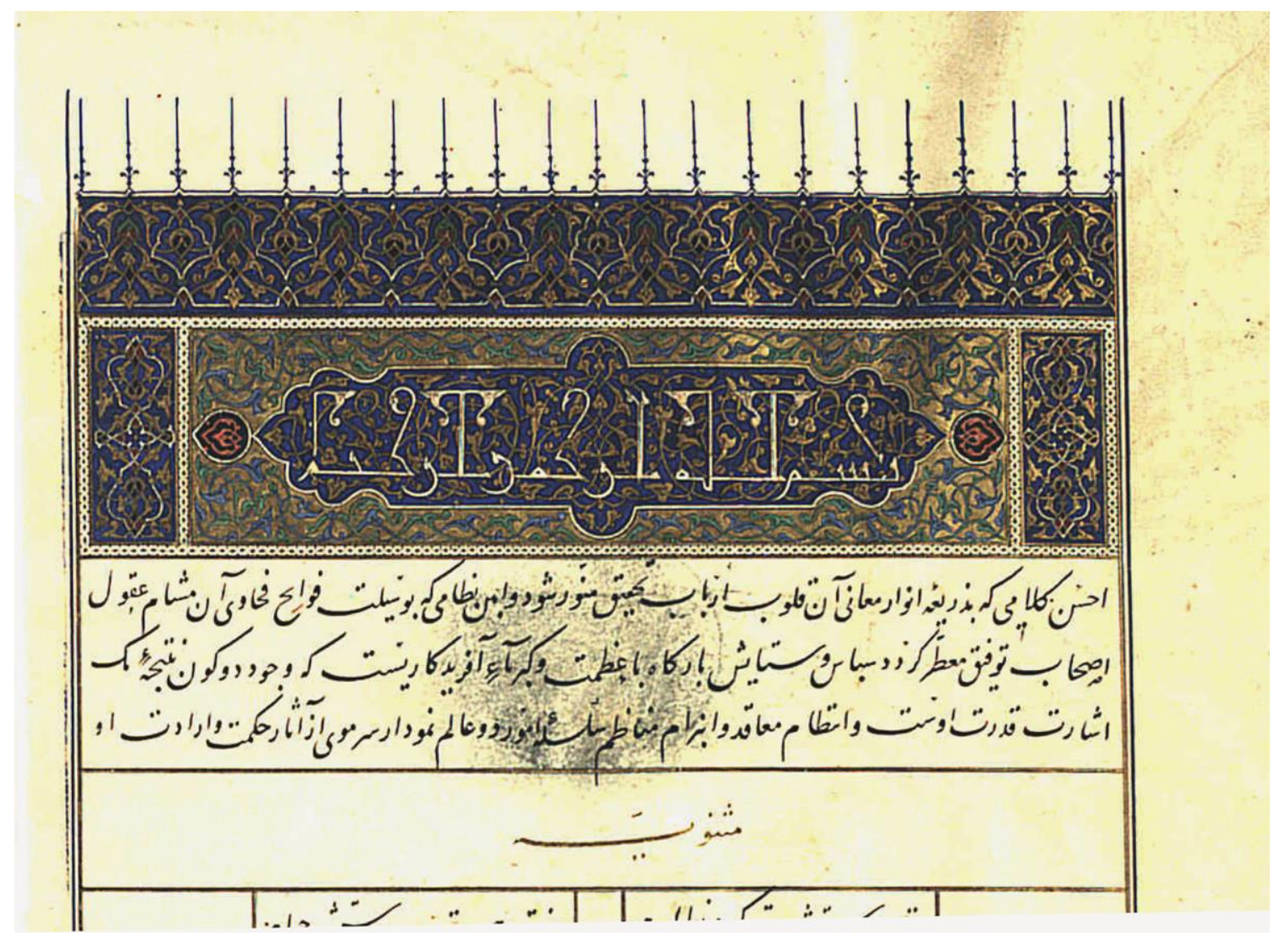

Fig. 3 


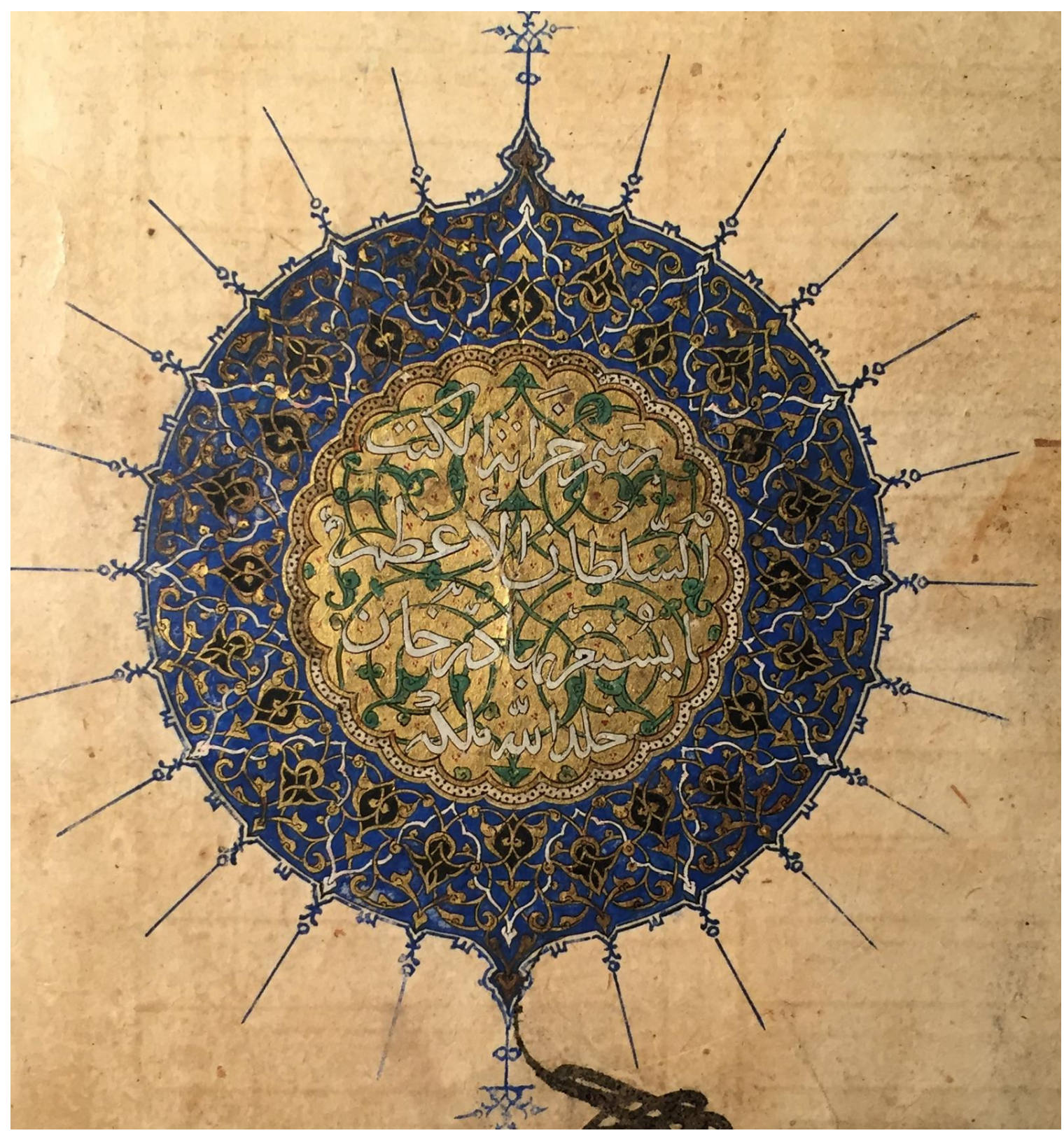

Fig. 4 


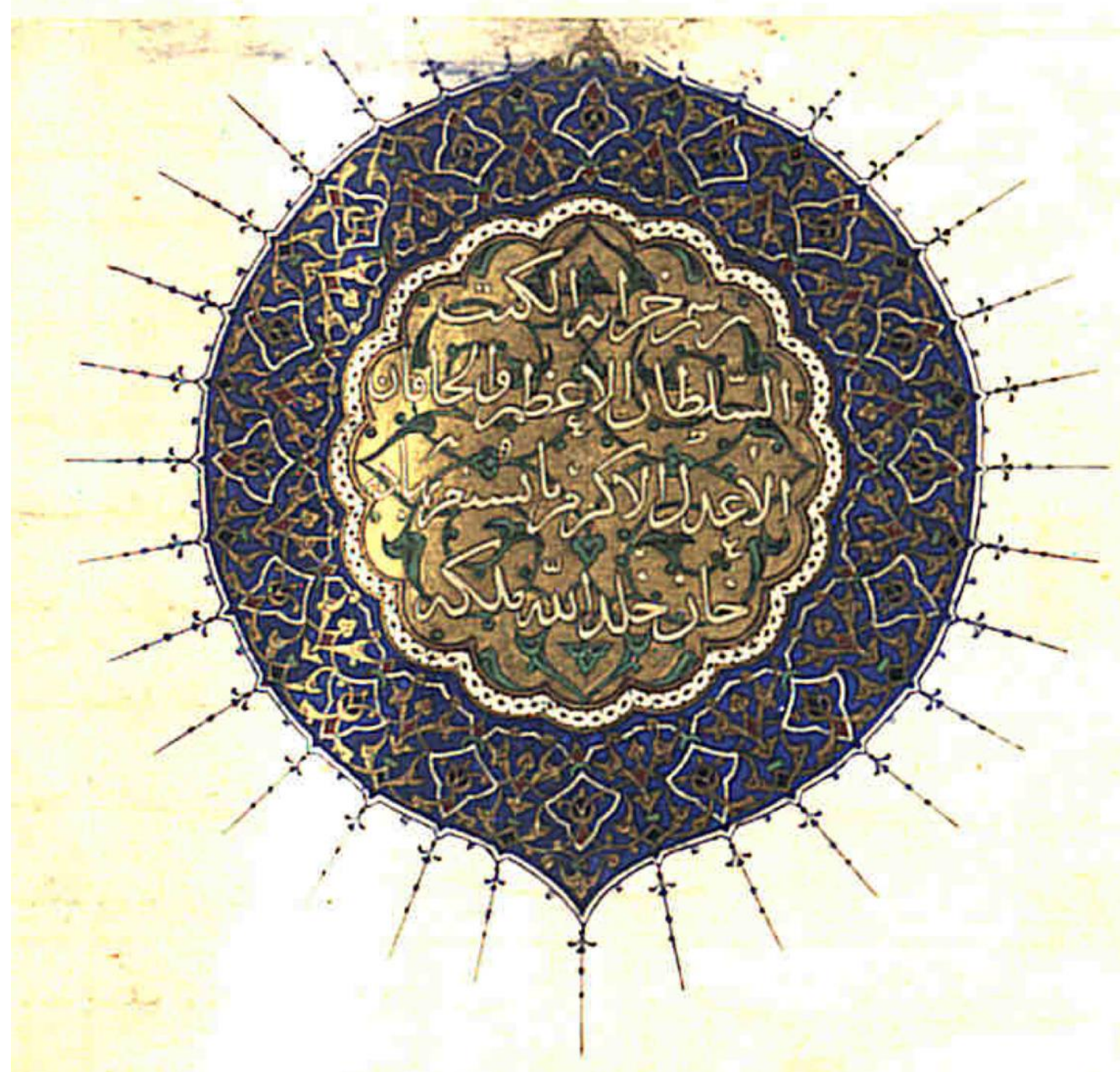

Fig. 5 


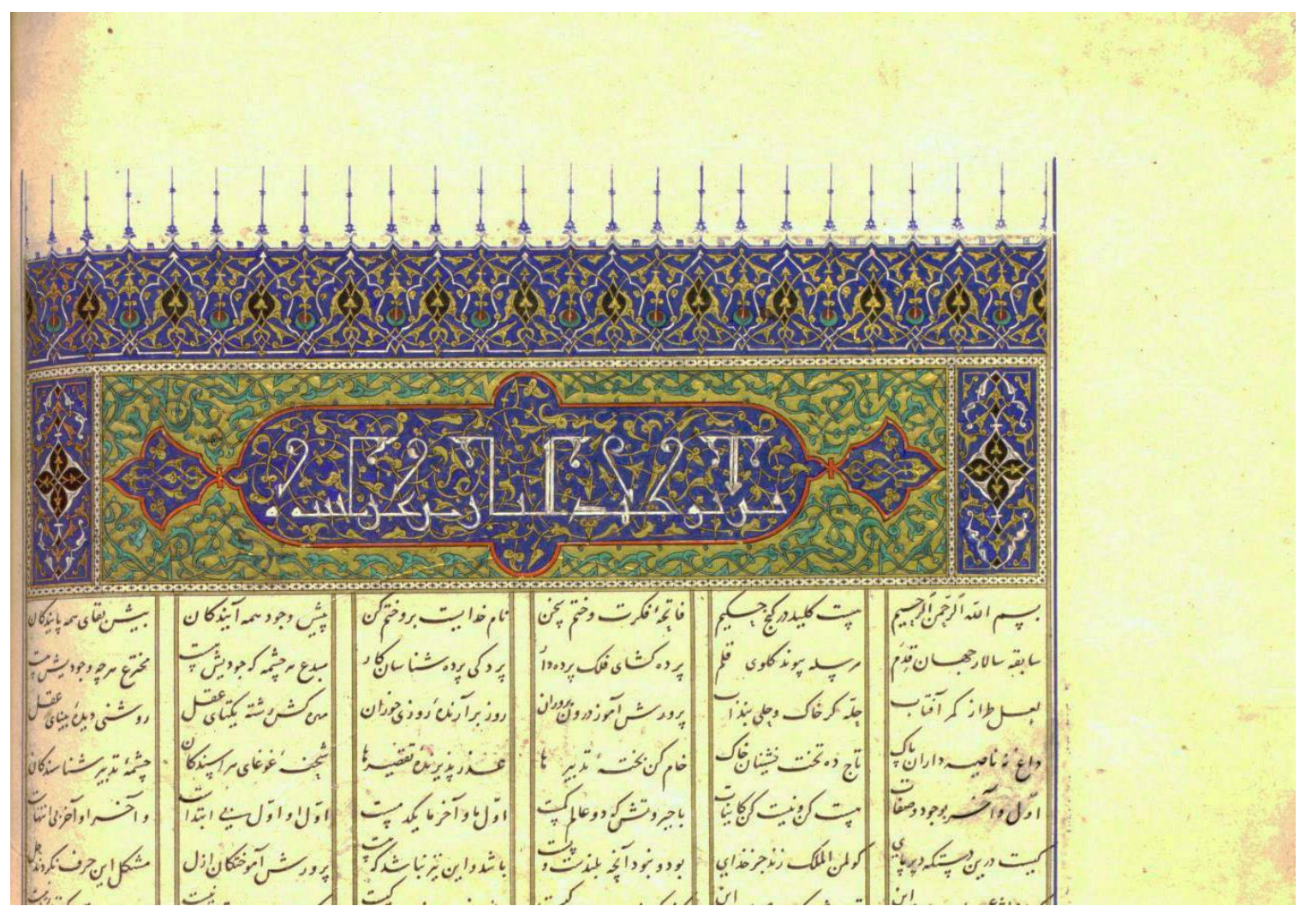

Fig. 6 


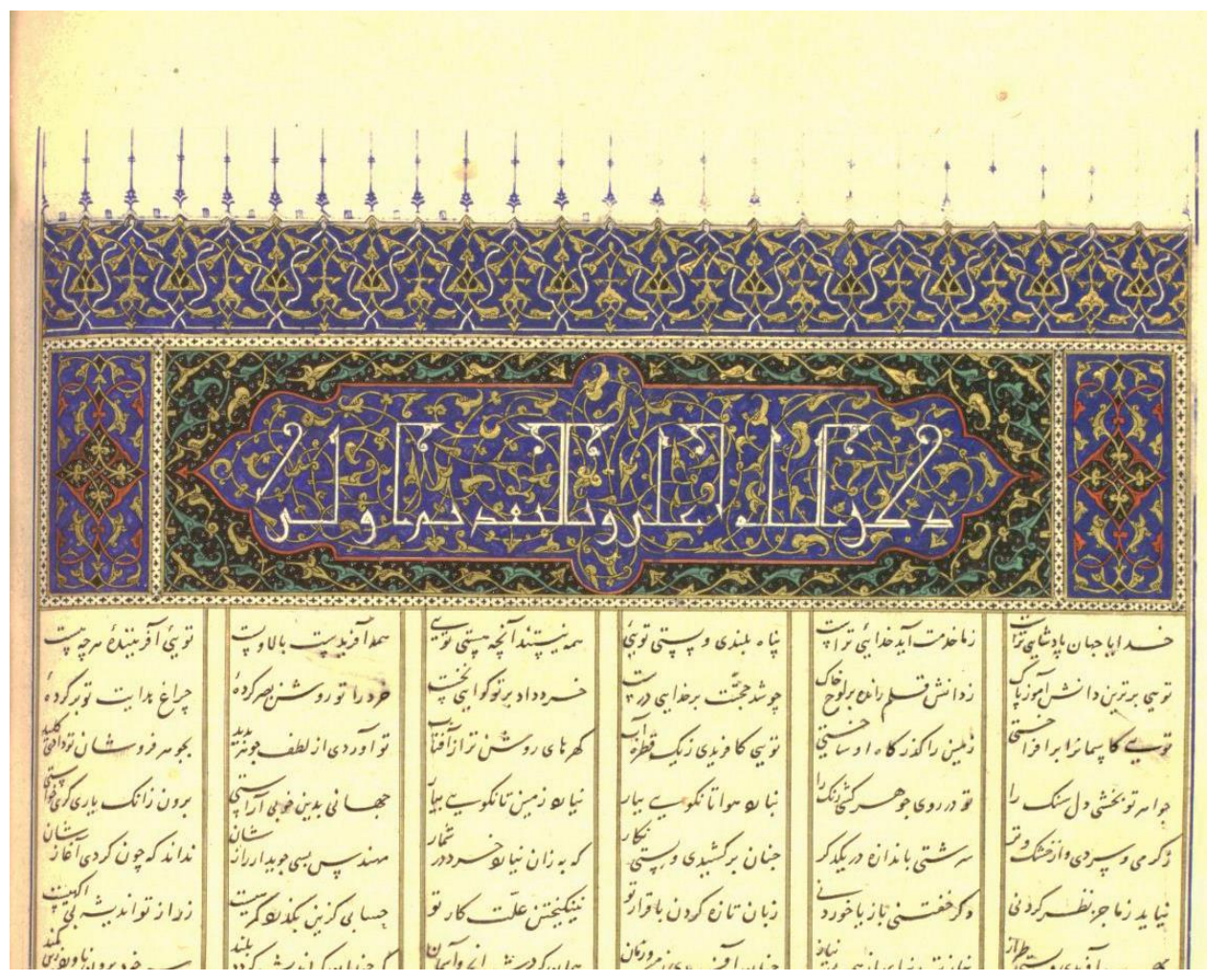

Fig. 7 


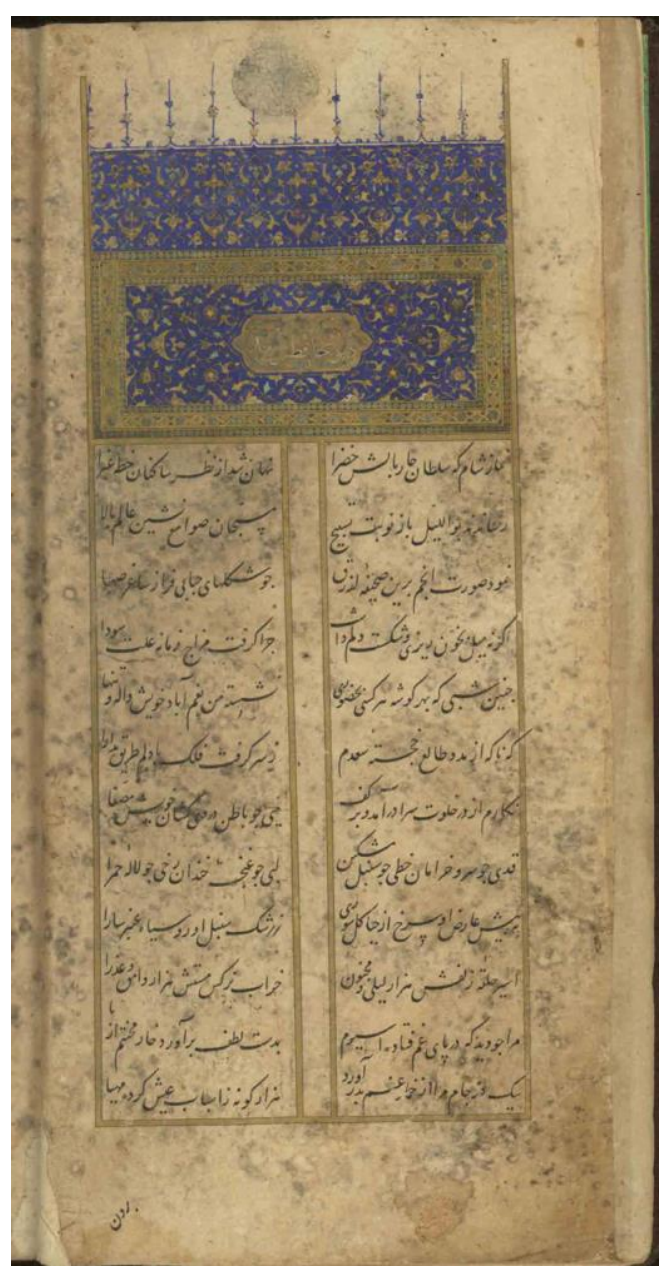

Fig. 8 


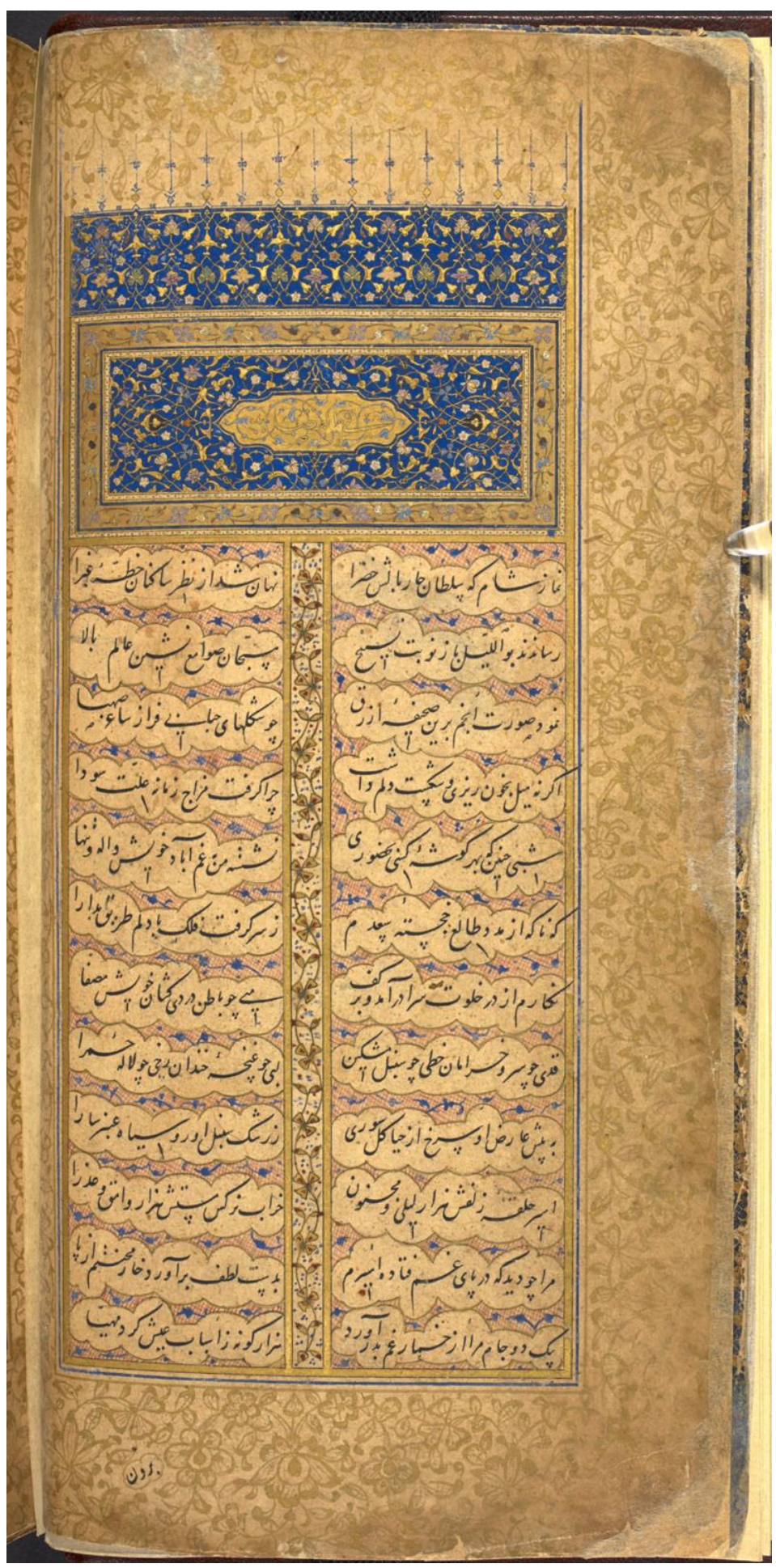

Fig. 9 